\title{
Haematological Values in the Serotine Bat, Eptesicus serotinus (Schreber, 1774)
}

\author{
Elżbieta WOŁK \& Andrzej L. RUPRECHT
}

Wolk E. \& Ruprecht A. L., 1988: Haematological values in the serotine bat, Eptesicus serotinus (Schreber, 1774). Acta theriol., 33, 40: 545-553. [With 3 Tables]

Haematological parameters were determined in 37 bats, Eptesicus serotinus, taking blood samples from 36 live animals at the period of their activity and from one hibernating bat (male). The high oxygen-carrying capacity of serotine bat blood is achieved owing to a very high haemoglobin level and high erythrocyte count, despite a relatively low index of the mean haemoglobin content in one cell. This contributes to easy complete saturation of haemoglobin with oxygen during intense gas exchange. Lower values of haemoglobin, erythrocytes and haematocrit in adult animals in spring and their lower body weight indicate their worse condition as compared to summer and autumn.

[Teachers Training Inst., Sienkiewicza 38, 87-100 Toruń, and Mammals Res. Inst., Polish Academy of Sciences, 17-230 Bialowieża, Poland]

\section{INTRODUCTION}

In studies on the physiological ecology of bats the attention is paid mainly to explanation of the mechanisms responsible for a high metabolic rate during active flying, and high weight-specific basal metabolic rates (McNab, 1982). Jürgens et al. (1981) studied the mechanisms of adaptation of bats to flying, especially the oxygen-carrying capacity of blood and conditions of gas exchange in bats with low body weight. The haematological parameters modifying directly the system of oxygen uptake and delivery in bats were investigated initially in the 1930s (Worth, 1932) and since that time the conditions of oxygen transport in certain bat species have become known (Grundboeck \& Krzanowski, 1957; Sealander, 1964; Dunaway \& Lewis, 1965; Davis et al., 1967; Valdivieso \& Tamsitt, 1971; Caire et al., 1981). A number of investigations were done on the haematological parameters in hibernating bats, that is at a time of greatly reduced oxygen requirements and decreased resistance (e.g. Krutzsch \& Hughes, 1959; Jaeger, 1963; Bruce \& Wiebers, 1971; Caire et al., 1981; Liang et al., 1984; Wołk \& Bogdanowicz, 1987). Besides that, Bassett \& Wiederhielm (1984) reported postnatal changes in the haematology of Antrozous pallidus (Le Conte, 1856). Our knowledge of these problems is, however, still incomplete (Riedesel, 1977). 
The purpose of the present study was to obtain the haematological parameters, of the erythrocyte and leucocyte systems, in one of the largest European bats, Eptesicus serotinus (Schreber, 1774), and to elucidate the relationships between the values of these parameters and the season, age and sex of the animals. The blood parameters of this bat were compared with those of terrestrial animals of similar body weight, rodents and Insectivora.

\section{MATERIAL AND METHODS}

The haematological parameters were determined in 37 bats. Thirty-six of them were caught in ornithological nets at the time of activity of these animals (from April to October) in the years 1983-1985, and one hibernating male was caught in March 1984. All these bats were caught in the Polana Bialowieska (Bialowieża Glade; NE Poland). The caught bats were ringed and placed in cloth bags containing moist cotton and were brought immediately to the laboratory. After several to about 20 hours blood samples were collected from live unanaesthetized animals from a cut wing vein of propatagium. When this was not possible (in some animals vasospasm of the wing membrane prevented blood outflow) a large vessel on the uropatagium was cut ${ }^{1}$. Besides that, the bats were weighed, their sex and age were determined. For age determination the presence or absence of epiphyseal cartilages and body weight were considered. Young animals born in the year of their catching (juveniles) and adult animals were distinguished.

The haemoglobin content $(\mathrm{Hb})$ was determined using the standard procedure for cyanmethaemoglobin determination with Ljungberg's haemometer. Haematocrit value (Hct) was determined by the haematocrit method. Erythrocytes (RBC count) were counted in a Thoma chamber. The diameter of red blood cells (RBC diam.) was measured with a Zeiss micrometric eyepiece in smears, after staining them by Pappenheim's method. These data served for calculation of the mean corpuscular haemoglobin ( $\mathrm{MCH})$, mean corpuscular haemoglobin concentration (MCHC), mean corpuscular volume (MCV) and mean thickness of erythrocyte (RBC thick.). White blood cells (WBC) were counted in Bürker chamber and the differential white blood cell count was obtained from blood smears with Pappenheim stain examined under oil immersion using standard counting techniques.

The $p$ values were calculated using Student's $t$ test, accepting $p<0.01$ as highly significant, while $p>0.05$ was not significant.

\section{RESULTS}

No statistically significant differences were observed between the values of haematological parameters in males and females. The only exception was a higher value of RBC diam. in adult males caught in spring

1 The bats freed after blood sampling flew away in good condition. The wounded vessels healed excellently as observed when the bats were caught again (two bats) after 18 days and after 4 months. 
$(p<0.01)$. However, in adult females the values of $\mathrm{Hb}, \mathrm{RBC}$ count and $\mathrm{RBC}$ diam. as well as Het were slightly lower, and the $\mathrm{MCH}$ value was slightly higher than in a corresponding group of males (Table 1).

The mean values of the haematological parameters and body weight were compared in the following age groups and seasons of the year (within each sex separately): (1) adult females caught in spring, (2) juvenile females caught in summer and autumn, (3) adult females caught in autumn, (4) adult males caught in spring and summer, (5) juvenile males caught in autumn (Tables 1 and 2). Groups: (6) adult males caught in autumn and (7) the hibernating male, were disregarded in statistical calculations in view of small number of animals.

Highly significantly higher values were found of three main erythrocyte parameters in juvenile females in relation to adult females, that is: Hb content $(p<0.001), \mathrm{RBC}$ count $(p<0.01)$ and Hct value $(p<0.001)$. Juvenile females were also significantly heavier than adult ones $(0.02<$ $p<0.05$ ). A highly significant difference was found between adult females caught in spring and autumn only in the haematocrit value $(p<0.001)$, which was higher in autumn. The $\mathrm{RBC}$ count and $\mathrm{Hb}$ content were also higher in autumn, although no significant difference was noted. Besides that, the adult females had a greater body weight in autumn $(0.001<p<0.01)$. No differences were found in haematological parameters and body weight between juvenile and adult females in autumn (Table 1 and 2).

The leucocyte parameters in E. serotinus showed a great variability, similarly as in other species of small mammals (see Wołk, 1985) and were not significantly different between age groups, sexes and seasons.

\section{DISCUSSION}

The $\mathrm{RBC}$ and WBC parameters in E. serotinus were essentially within the range of values found in other insectivorous bats (Lidicker \& Davis, 1955; Krutzsch \& Wimsatt, 1963; Dunaway \& Lewis, 1965). The RBC count and Het value in this species are slightly higher than those reported for a similar species E. fuscus (Palisot de Beauvois, 1796) by Dunaway \& Lewis (1965). In two examined individuals of $E$. fuscus these authors found $\mathrm{RBC}$ count $11.96 \times 10^{6} \mu \mathrm{l}$ and Hct values 46 . Evidently lower $\mathrm{Hb}$ values were found in Nyctalus noctula (Schreber, 1774), Myotis myotis (Borkhausen, 1797), Myotis natterei (Kuhl, 1817) and Plecotus auritus (Linnaeus, 1758) by Grundboeck \& Krzanowski (1957). Slightly lower values of $\mathrm{Hb}$ content and $\mathrm{RBC}$ count were found in pallid bat (Bassett \& Wiederhielm, 1984), and in the case of this species this seemed 
Table 1

Hematological parameters and body

\begin{tabular}{|c|c|c|c|c|c|c|}
\hline \multicolumn{7}{|l|}{ A. Females } \\
\hline \multirow[t]{3}{*}{ Item } & \multicolumn{2}{|c|}{$\begin{array}{c}\text { Apr., June } \\
\text { (ad.) }\end{array}$} & \multicolumn{2}{|c|}{$\begin{array}{l}\text { Aug., Sept., Oct. } \\
\text { (juv.) }\end{array}$} & \multicolumn{2}{|c|}{$\begin{array}{l}\text { Aug., Sept. } \\
\text { (ad.) }\end{array}$} \\
\hline & $\overline{\mathbf{x}}$ & SD & $\overrightarrow{\mathrm{x}}$ & SD & $\overline{\mathrm{x}}$ & SD \\
\hline & \multicolumn{2}{|c|}{1} & \multicolumn{2}{|c|}{2} & \multicolumn{2}{|c|}{3} \\
\hline Hb., g/dl & 17.30 & 0.69 & 20.16 & 0.65 & 18.20 & 3.02 \\
\hline $\mathrm{RBC}, 10^{6} / \mu \mathrm{l}$ & 12.39 & 1.34 & 14.88 & 1.42 & 14.53 & 1.82 \\
\hline $\mathrm{MCH}, \mathrm{pg}$ & 14.11 & 1.99 & 13.62 & 1.31 & 12.68 & 1.86 \\
\hline Het, $\%$ & 47.00 & 3.00 & 56.33 & 2.39 & 56.66 & 2.78 \\
\hline RBC diam., $\mu$ & 5.71 & 0.02 & 5.75 & 0.06 & 5.73 & 0.06 \\
\hline RBC thick., $\mu$ & 1.41 & 0.13 & 1.46 & 0.10 & 1.51 & 0,18 \\
\hline $\mathrm{MCV}, \mu^{3}$ & 36.27 & 3.38 & 38.04 & 2.73 & 39.09 & 4.44 \\
\hline $\mathrm{MCHC}, \%$ & 36.36 & 2.97 & 35.77 & 1.28 & 33.10 & 4.04 \\
\hline $\mathrm{WBC}, \times 10^{3} / \mu \mathrm{l}$ & 4.41 & 2.30 & 4.48 & 2.37 & 4.23 & 1.99 \\
\hline Neutrophils, $\%$ & 34.00 & 12.40 & 20.40 & 10.50 & 24.30 & 9.40 \\
\hline$\times 10^{3 / \mu 1}$ & 1.31 & 0.41 & 0.92 & 0.64 & 1.01 & 0.58 \\
\hline $\begin{array}{c}\text { Eosinophils, } \% \\
\times 10^{3} / u 1\end{array}$ & \multicolumn{2}{|c|}{ sporadically } & $\begin{array}{l}2.55 \\
0.11\end{array}$ & $\begin{array}{l}2.74 \\
0.09\end{array}$ & \multicolumn{2}{|c|}{ sporadically } \\
\hline Basophils, $\%$ & \multicolumn{2}{|c|}{ sporadically } & \multicolumn{2}{|c|}{ sporadically } & 1.66 & 1.15 \\
\hline Lymphocytes, $\%$ & 64.25 & 12.10 & 76.11 & 9.70 & 73.60 & \\
\hline$\times 10^{3} / \mu 1$ & 3.02 & 2.19 & 3.42 & 1.93 & 3.13 & 1.56 \\
\hline Monocytes, $\%$ & 1.25 & 0.50 & 1.75 & 0.50 & 1.62 & 1.06 \\
\hline$\times 10^{3} / \mu 1$ & 0.06 & 0.05 & 0.07 & 0.03 & 0.05 & 0.01 \\
\hline $\mathrm{I} / \mathrm{N}$ ratio & 2.18 & 2.00 & 5.32 & 3.85 & 3.86 & 2.80 \\
\hline Body weight, g & 20.97 & 1.95 & 25.11 & 2.84 & 25.91 & 2.72 \\
\hline \multicolumn{3}{|c|}{ Number of animals } & \multicolumn{2}{|c|}{$\mathrm{n}=\mathbf{9}$} & \multicolumn{2}{|c|}{$\mathbf{n}=\mathbf{1 0}$} \\
\hline
\end{tabular}

* three individual observations: $0,045,0.245$, and 0.060 .

to depend on its greater body mass $(31.4-42.0 \mathrm{~g})$, since an inverse correlation exists between body size and oxygen-carrying capacity of blood in mammals (Burke, 1966; Wolk, 1974). The higher haematocrit value in pallid bat (Bassett \& Wiederhielm, 1984) in comparison to serotine bat was caused, probably, by greater diameter and volume of erythrocytes.

The lower values of $\mathrm{Hb}$ content, $\mathrm{RBC}$ count and Hct, as well as a lower body weight of adult female E. serotinus in spring, in relation to proper values in the remaining groups of females (all differences were statistically significant) (Table 1 and 2) were an evidence of their worse conditions. Similarly worse was apparently the condition measured with the same parameters in males caught in spring as compared to males in summer and autumn. Perhaps, this was the effect of worse nutritional conditions in spring (less flying insects in air) than in summer and 
weight ( $\overline{\mathrm{x}}$ and SD) of the serotine bat.

\begin{tabular}{|c|c|c|c|c|c|c|c|}
\hline \multicolumn{8}{|l|}{ B. Males } \\
\hline \multirow[t]{3}{*}{ Item } & \multicolumn{2}{|c|}{$\begin{array}{l}\text { May, June, July } \\
\text { (ad.) }\end{array}$} & \multicolumn{2}{|c|}{$\begin{array}{l}\text { Aug. Sept., Oct. } \\
\text { (juv.) }\end{array}$} & \multicolumn{2}{|c|}{$\begin{array}{l}\text { Aug., Sept. } \\
\text { (ad.) }\end{array}$} & \multirow[t]{2}{*}{$\begin{array}{l}\text { March (ad) } \\
\text { hibernating }\end{array}$} \\
\hline & $\overline{\mathbf{x}}$ & SD & $\overline{\mathbf{x}}$ & SD & $\overline{\mathbf{x}}$ & SD & \\
\hline & \multicolumn{2}{|c|}{4} & \multicolumn{2}{|c|}{5} & \multicolumn{2}{|c|}{6} & 7 \\
\hline Hb., g/dl & 17.50 & 1.77 & 19.98 & 1.69 & 19.5 & 18.6 & 20.40 \\
\hline RBC, $10^{6} / \mu \mathrm{l}$ & 12.83 & 1.86 & 14.91 & 1.82 & 15.05 & 14.32 & 16.23 \\
\hline $\mathrm{MCH}, \mathrm{pg}$ & 13.19 & 2.15 & 13.46 & 0.78 & 12.96 & 12.99 & 12.57 \\
\hline Het, $\%$ & 49.16 & 6.46 & 56.00 & 4.00 & 56 & 52 & 54 \\
\hline RBC diam., $\mu$ & 5.81 & 0.05 & 5.71 & 0.04 & 5.80 & 5.81 & 5.86 \\
\hline RBC thick., $\mu$ & 1.47 & 0.32 & 1.47 & 0.12 & 1.41 & 1.37 & 1.23 \\
\hline $\mathrm{MCV}, \mu^{3}$ & 39.15 & 8.40 & 37.81 & 3.13 & 37.21 & 36.31 & 33.27 \\
\hline $\mathrm{MCHC}, \%$ & 36.21 & 3.79 & 35.65 & 0.91 & 34.82 & 35.77 & 37.78 \\
\hline WBC, $\times 10^{8} / \mu \mathrm{l}$ & 5.37 & 2.88 & 3.13 & 0.82 & 7.500 & 7.200 & 2.650 \\
\hline Neutrophils, $\%$ & 22.80 & 7.50 & 30.40 & 8.40 & 43 & 24 & 87 \\
\hline$\times 10^{3} / \mu 1$ & 1.25 & 0.87 & 0.98 & 0.24 & 3.255 & 1.728 & 2.306 \\
\hline Eosinophils, \% & 0 & - & \multicolumn{2}{|c|}{ sporadically } & & 4 & 0 \\
\hline$\times 10^{3} / \mu 1$ & 0 & - & \multirow{3}{*}{\multicolumn{2}{|c|}{ sporadically }} & 0.075 & 0.288 & 0 \\
\hline Basophils, \% & 0 & - & & & 0 & 2 & 0 \\
\hline$\times 10^{8} / \mu 1$ & 0 & - & & & 0 & 0.144 & $\mathbf{0}$ \\
\hline Lymphocytes, \% & 76.66 & 8.00 & 67.40 & 9.10 & 55 & 69 & 13 \\
\hline$\times 10^{3} / \mu 1$ & 4.07 & 2.10 & & 0.73 & 4.125 & 4.963 & 0.345 \\
\hline Monocytes, \% & \multirow{2}{*}{\multicolumn{2}{|c|}{ sporadically }} & \multirow{2}{*}{\multicolumn{2}{|c|}{ sporadically }} & & & 0 \\
\hline$\times 10^{3} / \mu 1$ & & & & & 0.075 & 0.072 & 0 \\
\hline I. $\mathrm{N}$ ratio & 3.76 & 1.53 & 2.45 & 1.11 & 1.28 & 2.88 & 0.15 \\
\hline Body weight, g & 19.55 & 1.25 & 23.66 & 3.49 & 26.00 & 22.00 & 17.0 \\
\hline \multicolumn{3}{|l|}{ Number of animals } & \multicolumn{2}{|c|}{$n=5$} & \multicolumn{2}{|c|}{$\mathrm{n}=\mathbf{2}$} & $n=1$ \\
\hline
\end{tabular}

Table 2

Significant differences between values of haematological parameters and body weight of the serotine bat. Data with no significant differences were omitted. 1 - Females ad., Apr., June, 2 - Females juv., Aug.-Oct., 3 - Females ad., Aug.-Sept., 4 - Males ad., May-July, 5 - Males juv., Aug.-Oct.

\begin{tabular}{lcclc}
\hline Parameters & \multicolumn{4}{c}{ Groups } \\
\cline { 2 - 5 } & $1-2$ & $1-3$ & $2-3$ & $4-5$ \\
\hline Hb & $p<0.001$ & $p>0.05$ & $p>0.05$ & $p>0.05$ \\
RBC count & $0.01<p<0.05$ & $p>0.05$ & $p>0.05$ & $p>0.05$ \\
Het & $p<0.001$ & $p<0.001$ & $p>0.05$ & $p>0.05$ \\
RBC diam. & $p>0.05$ & $p>0.05$ & $p>0.05$ & $p<0.01$ \\
Body weight & $0.02<p<0.05$ & $0.001<p<0.01$ & $p>0.05$ & $0.02<p<0.05$ \\
\hline
\end{tabular}

autumn. In a certain degree the lower values of the basic RBC parameters (Hb, RBC count, Hct) in adult females in spring might have depended on the fact that many of them were probably pregnant at that 
time. A similar pregnancy-associated "anaemia" is observed in certain other species of small mammals (Wołk, 1974). This interpretation is confirmed by the observation that the differences between RBC parameters in juvenile and adult males caught in summer and autumn are lower (significantly greater was only $\mathrm{RBC}$ diameter in adult animals: $0.02<$ $p<0.05$ ) (Table 1 and 2).

The haematological parameters during hibernation were obtained from only one animal. E. serotinus hibernates individually, in contrast to most bat species, which makes difficult obtaining of material for examinations. The obtained results (Table 1) are insufficient for more general conclusions. According to our observations the blood of hibernating E. serotinus clotted much more slowly than that of active animals. This long clotting time in winter as compared with summer was observed also in Myotis lucifugus (Le Conte, 1831) (Smith et al., 1954). Lewis (1977) observed in Pteropus giganteus (Brünnich, 1782) prolongation of activated partial thromboplastin and thrombin times (as compared with most other mammals).

The values of RBC parameters in hibernating E. serotinus were much higher than in hibernating (Myotis daubentoni (Kuhl, 1817) (Wołk \& Bogdanowicz, 1987) and higher also than in active E. serotinus (Table 1). Increased $\mathrm{RBC}$ count during hibernation was reported also by Kallen (1968), and increased Hct value was found by Bruce \& Wiebers (1971),

Table 3

Comparison of the RBCs parameters among small mammals (in August-October). Numbers of samples are given in brackets.

\begin{tabular}{|c|c|c|c|}
\hline Parameters & $\begin{array}{l}\text { Neomys } \\
\text { fodiens }{ }^{1} \\
\text { (18) }\end{array}$ & $\begin{array}{c}\text { Clethrionomys } \\
\text { glareolus }{ }^{2} \\
(25)\end{array}$ & $\begin{array}{l}\text { Eptesicus } \\
\text { serotinus } \\
\text { (14) }\end{array}$ \\
\hline $\begin{array}{l}\text { Body weight } \\
\text { (g) }\end{array}$ & 15.7 & $16.1 *$ & 24.6 \\
\hline $\mathrm{Hb}$ & 16.6 & 17.2 & 20.1 \\
\hline RBC count & 11.71 & 12.13 & 14.9 \\
\hline $\mathrm{MCH}$ & 13.6 & 143 & 13.6 \\
\hline Het & 49.4 & 48.8 & 56.2 \\
\hline RBC diam. & 5.38 & 5.30 & 5.74 \\
\hline RBC thick. & 1.80 & 1.86 & 1.47 \\
\hline $\mathrm{MCV}$ & 41.1 & 40.6 & 38.0 \\
\hline $\mathrm{MCHC}$ & 33.9 & 35.3 & 35.7 \\
\hline
\end{tabular}

1 Wolk, 1974; ${ }^{2}$ Kostelecka-Myrcha, 1967. * Average body weight was calculated by us for 30 subadult bank voles (15 males and 15 females) caught in September 1967 in Bialowieża Primeval Forest; ${ }^{3}$ This paper. Mean values for males and females are given. 
while some other authors observed a reverse pattern of changes (Lidicker \& Davis, 1955; Krutzsch \& Hughes, 1959; Kallen \& Wimsatt, 1962; Davis et al., 1967; Liang et al., 1984). Falling lymphocyte and increased neutrophil counts observed in the hibernating $E$. serotinus (Table 1) were observed also in hibernating Myotis myotis (Jaeger, 1963).

The oxygen-carrying capacity of blood of $E$. serotinus was compared with this capacity in young but already mature, sexually inactive nonflying mammals of similar body weight but with a different way of life: Neomys fodiens (Pennant, 1771) which has an amphibian mode of life, identical in both insectivores but lower than in the rodent (Table 3). Neomys fodiens and E. serotinus, both insectivorous, differ in RBC parameters: $E$. serotinus has considerably higher values of $\mathrm{Hb}, \mathrm{RBC}$ and Hct (with the intermediate values found in Clethrionomys glareolus). On the other hand, the $\mathrm{Hb}$ content in the red blood cell (MCH index) was identical in both insectivores but lower than in the rodent (Table 3). Lower MCH values with similar red blood cell sizes cause that the amount of $\mathrm{Hb}$ per one unit of erythrocyte surface is lower, which favours full saturation of haemoglobin with oxygen, despite a very high rate of gas exchange in the lungs. Thus the efficiency and economy of this process are better. This is probably important for the diving Neomys fodiens and the flying. $E$. serotinus. Jürgens et al. (1981) found that, in five studied species of bats, adaptation to the requirements of high metabolic rate connected with flight is based mainly on relatively greater size of the heart and lungs and higher values of $\mathrm{Hb}, \mathrm{RBC}$ count, Het than in small terrestrial mammals. On the other hand, no differences are found between these two groups of mammals with respect to haemoglobin affinity for oxygen and Bohr's factor. In the case of $E$. serotinus the view of Jürgens et al. (1981) that the diameter of bat erythrocytes is smaller than that of terrestrial mammals has not been confirmed (Table 3). The diameter of erythrocytes of $M$. daubentoni was also $5.8 \mu \mathrm{m}$ (Wołk \& Bogdanowicz, 1987).

In summary, it is worth stressing that the high blood oxygen carrying capacity in $E$. serotinus is due, in the first place, to a high haemoglobin level and a high number of erythrocytes with a relatively low index of the mean corpuscular haemoglobin content ( $\mathrm{MCH})$ increasing the economy of the process of gas exchange. Lower values of $\mathrm{Hb}, \mathrm{RBC}$ count and Hct in adult bats in spring, in connection with lower body weight, suggest a worse condition of the animals in that season as compared to summer and autumn. 


\section{REFERENCES}

1. Bassett J. E. \& Wiederhielm C. A., 1984: Postnatal changes in hematology of the bat Antrozous pallidus. Comp. Biochem. Physiol., 78A: 737-742.

2. Bruce D. S. \& Wiebers J. E., 1971: Hematocrit of Myotis lucifugus during hibernation and forced immobility. Bat Res. News, 12: 41-43.

3. Burke J. D., 1966: Vertebrate blood oxygen capacity and body weight. Nature, 212: $46-48$.

4. Caire W., Cox B. L. \& Levescy B., 1981: Some normal blood values of Myotis velifer (Vespertilionidae). J. Mammal., 62: 436-439.

5. Davis W. H., Cawein M. J., Hassell M. D. \& Lappat E. J., 1967: Winter and summer circulatory changes in refrigerated and active bats, Myotis lucifugus. J. Mammal., 48: 132-134.

6. Dunaway P. B. \& Lewis L. L., 1965: Taxonomic relation of erythrocyte count, mean corpuscular volume and body weights in mammals. Nature, 205: 481$-484$.

7. Grundboeck M. \& Krzanowski A., 1957: Morphological investigations on the blood of some European species of bats. Zool. Pol., 8: 349-368.

8. Jaeger R., 1963: Serologisch-hämatologische und immunologische Untersuchungen an winterschlafenden Fledermäusen (Myotis myotis S.). Experientia, 19: $596-598$.

9. Kallen F. C., 1960: Vascular changes related to hibernation in the vespertilionid bat Myotis lucifugus. Bull. Mus. comp. Zool. Harv. Coll., 124: 373-386.

10. Kallen F. C. \& Wimsatt W. A., 1962: Circulating red cell volume in little brown bat in summer. Am. J. Physiol., 203: 1182-1184.

11. Kostelecka-Myrcha A., 1967: Variation of morpho-physiological indices of blood in Clethrionomys glareolus (Schreber, 1780). Acta theriol., 12: 191-222.

12. Krutzsch P. H. \& Hughes A. H., 1959: Hematological changes with torpor in the bat. J. Mammal., 40: 547-554.

13. Lewis J. H., 1977: Comparative hematology: Studies on Chiroptera, Pteropus giganteus. Comp. Biochem. Physiol., 58A: 103-107.

14. Liang R., Xiao F. \& Wang M., 1984: On the morpho-physiological indices of long-winged bat in the period of hibernation. Acta theriol. sin., 4: 167-175 .

15. Lidicker W. A., Jr. \& Davis W. H., 1955: Changes in splenic weight associated with hibernation in bats. Proc. Soc. Exp. Biol. Med., 89: 640-643.

16. McNab B. K., 1982: Evolutionary alternatives in the physiological ecology of bats. [In: "Ecology of Bats". Ed. Kunz T. H.]. Plenum Press: 151-200. New York.

17. Riedesel M. L., 1977: Blood physiology. [In: "Biology of Bats". Ed. Wimsatt W. A.]. Vol. III. Academic Press: 485-517. New York.

18. Sealander J. A., 1964: The infuence of body size, season, sex, age and other factors upon some blood parameters in small mammals. J. Mammal., 45: $598-616$.

19. Smith D. E., Lewis Y. S. \& Svihla G., 1954: Prolongation of clotting time in the dormant bat (Myotis lucifugus). Experientia, 10: 218.

20. Valdivieso D. \& Tamsitt J. R., 1971: Hematological data from tropical American bats. Can. J. Zool., 49: 31-36.

21. Wolk E., 1974: Variations in the hematological parameters of shrews. Acta theriol., 19: 315-346. 
22. Wolk E., 1985: Hematology of the early postnatal development in free-ranging mammals. Zesz. nauk. Filii Uniw. Warsz., 48, Prace biol., 10: 31-41.

23. Wolk E. \& Bogdanowicz W., 1987: Hematology of the hibernating bat: Myotis daubentoni. Comp. Biochem. Physiol., 88A: 637-639.

24. Worth R., 1932: Observations on the blood and blood-forming organs of certain local Chiroptera. Folia haematol., 48: 337-354.

Received 18 March 1988, Accepted 8 June 1988.

Elżbieta WOLK \& Andrzej L. RUPRECHT

\section{PARAMETRY HEMATOLOGICZNE MROCZKA POŹNEGO, EPTESICUS SEROTINUS (SCHREBER, 1774)}

\section{Streszczenie}

Zbadano przyżyciowo parametry hematologiczne u 37 mroczków późnych z populacji białowieskiej, uwzględniając zmienność płciową, wiekową i sezonową. Próby krwi pobierano od odłowionych, zaobrączkowanych i następnie wypuszczanych na wolność nietoperzy w okresie ich aktywności i od jednego hibernującego samca. Stwierdzono, że wysoka transportowa pojemność tlenowa mroczka późnego osiągana jest dzięki wysokiemu poziomowi hemoglobiny oraz dużej liczbie czerwonych krwinek. Natomiast wskaźnik średniej zawartości hemoglobiny w krwince (MCH) jest stosunkowo niski (Tabele 1-3). Sprzyja to pelnemu wysycaniu się hemoglobiny tlenem w warunkach intensywnej wymiany gazowej latającego ssaka. Obniżony poziom hemoglobiny $(p<0,001)$, liczby czerwonych krwinek $(0,01<p<0,05)$ i hematokrytu $(p<0,001) \mathrm{u}$ dorosłych samic z wiosny, jak również mniejsza masa ciała wskazują na ich gorszą kondycję w porównaniu $\mathrm{z}$ osobnikami $\mathrm{z}$ lata i jesieni (Tabele 1-2). U hibernującego osobnika stwierdzono obniżoną krzepliwość krwi i podwyższenie wartości hemoglobiny, liczby czerwonych krwinek i hematokrytu oraz obniżoną liczbę limfocytów polączoną z podwyższoną liczbą neutrofilów (Tabela 1). 